\title{
Analysis of climate types: Main strategies for sustainable decisions in agricultural areas of Carabobo, Venezuela
}

\author{
Barlin Orlando Olivares ${ }^{1, *}$; Rafael Hernández ${ }^{2}$; Richard Coelho ${ }^{2}$; Juan Carlos \\ Molina²; Yessica Pereira $^{2}$ \\ 1 Universidad de Córdoba, Programa Iberoamericano de Doctores en Agroalimentación, Andalucía, España. \\ 2 Instituto Nacional de Meteorología e Hidrología (INAMEH), Gerencia de Meteorología Aplicada. Baruta estado \\ Miranda, Venezuela.
}

Received October 16, 2017. Accepted April 17, 2018.

\begin{abstract}
Recently, the agricultural zones of Carabobo present problems with the water available for crops influenced by the fluctuation between Precipitation and Potential Evapotranspiration. It is for this reason that the need arises to analyze the climatic types according to the degree of humidity. The Climatic Hydrological Balance methodology was used for 25 rainfall stations in Carabobo, Venezuela, for a period of common registration (1969 - 1999). The results show that four regions were found where humidity behaves differently, the greatest excesses are to the south of the state and it was found that the climatological stations located north of Carabobo have a greater annual deficit. The most relevant agricultural areas are represented by a water index of $(-2.16$ to -18.96$)$; which determines a dry sub-humid climate with annual rainfall ranging between $921 \mathrm{~mm}$ and $1063 \mathrm{~mm}$. This study generated vital information in those agricultural areas that require additional irrigation or controls with structural drainage works that prevent certain crops sensitive to excess water from being damaged.
\end{abstract}

Keywords: agriculture; precipitation; climatology; water deficit.

\section{Introduction}

The First National Communication of Venezuela on Climate Change reveals the existence of spatial patterns in the geographical distribution of climatic variables, mainly in terms of precipitation values. Thus, there are some regions where the changes are not significant, while for other areas, reductions of up to $25 \%$ in precipitation values are expected (Olivares et al., 2017c).

Globally, climatology services provide information on many aspects of the climate and land system as a whole. Under the current context, the data are used to describe, represent and predict both the behavior of the whole climate system (in particular, the effect of man's activity on the climate) and the relationship between climate and other aspects of the natural environment (OMM, 2011; Olivares et al., 2016c).

The meteorological conditions of a region that influence the natural climatic variability, together with the interaction of the

* Corresponding author

E-mail: barlinolivares@gmail.com (B. Olivares). climatic elements, give way to the generation of the climatic types (Zubieta et al., 2017), that when interacting with the rest of the factors natural resources, will condition biodiversity in general, and the climate supply as potential to the demand that certain crops require in order to obtain profitable and sustainable harvested surfaces.

In particular, agricultural activities in the field are conditioned by climatic elements, especially temperature and precipitation (Alzate et al., 2018), which is why knowing the water regime of a region has valuable applications, aimed at minimizing risks in production processes, in addition to serving as a basis for crop zoning, characterization of droughts, determination of sowing seasons, irrigation scheduling and identification of drainage needs among others (Ruiz-Álvarez et al., 2012; Olivares et al., 2012; Olivares et al., 2013a; Rodríguez et al., 2013; Olivares et al., 2017b; Olivares et al., 2017c). The observations, predicttions and analyzes carried out in research 
allow the agricultural communities to increase livestock production and crop yield, as well as to plan the planting and harvesting seasons (Olivares, 2018).

In general, the tropical agricultural territories are inscribed in a space dominated by the scarcity of rainfall at a time of year, its high irregularity and the lack of agreement between the needs required by crops (potential evapotranspiration) and rainfall (Olivares et al., 2017a; García et al., 2017). Therefore, the relationships between rainfall and agriculture are often illustrated under the formula of water balances, which compare the average monthly rainfall with the estimated water requirements for crops. An agronomic criterion that allows knowing the climatic differentiation of the zones and the water needs of the crops in each place and time to ensure the production and income of the farmer.

Based on the above, Thornthwaite (1948) proposed a methodology for climates to be ordered according to the degree of humidity, taking into account the water needs of crops (evapotranspiration); and with the results of the Climatic Water Balance (BHC): excesses and deficits, the water index $(\mathrm{Im})$ is determined, which allows to group the climate in one of the most used classifications worldwide.

The knowledge of water deficits and excesses through the methodological application of the BHC is of great interest to determine the possibilities of rainfed and irrigated crops in the agricultural areas of Venezuela, because the exploitation of the arable land is carried out in most of it without knowing the potential characteristics of the climate, the soils, and the requirements of the crop, which does not allow to maximize the productivity, in addition, of the conservation and sustainnable management of the resources.

In Carabobo, more and more agricultural producers are deciding to optimize the use of water resources with investments that allow them to cope optimally with periods of water deficit in the dry season. Hence, the importance and the need to generate basic information on the climatic conditions that, together with the social and economic aspects, constitute the impulse to research and technological innovation for the development of scientifically based, economically profitable and environmentally sustainable activities in degraded agricultural areas, allowing a better quality of life for its inhabitants.

The objective of this study is to analyze the temporal variability of the water balance in the agricultural areas of the Carabobo state in Venezuela, with the firm purpose of interpreting and applying information about the past climate for decision making, sustainable development and improvement of information products, predictions and projections relating to climate.

\section{Materials and methods}

\section{Study zone}

The Carabobo state is located in the centernorth of the country, between the geographic coordinates $09^{\circ} 48^{\prime}$ and $10^{\circ} 35^{\prime}$ of Latitude North with $67^{\circ} 31^{\prime}$ and $68^{\circ} 26$ 'of West Longitude. It limits to the North with the Caribbean Sea, to the South with the Cojedes and Guárico States, to the East with the State of Aragua and to the West with the State of Yaracuy (Figure 1). It has an area of $4651 \mathrm{~km}^{2}$, including $281 \mathrm{~km}^{2}$ of the Lake of Valencia (Hernández et al., 2017); which represents $0.5 \%$ of the national territory. Of the total area, only $42,53 \%\left(1973 \mathrm{~km}^{2}\right)$ is potential for agricultural activity.

\section{Climate information}

Monthly precipitation data of 25 Conventional Pluviometric (CP) stations located in the state of Carabobo were used, from the Data Bank of the Data Processing and Quality Management of the National Institute of Meteorology and Hydrology (INAMEH) (Table 1).

These stations were selected because they possess a common period of 30 years of historical record from 1969 to 1999; this time lapse includes the largest number of stations with complete records of the Carabobo state, as suggested by the World Meteorological Organization (WMO, 2011). The included data were calculated with the monthly deglobal formulas and the missing ones were estimated through the Statistical Regression Method (Guevara, 2013).

Quality control was carried out on the monthly precipitation data to define the proportion of missing data, identify out-ofnormal values and observe the basic understanding of the distribution of the series (Parra and Cortez, 2005; Ablan et al., 2008; Olivares et al., 2013b); using the programs JMP v.6 (Jones and Sall, 2011), InfoStat v.11 (Di Rienzo et al., 2011).

Potential evapotranspiration (ETP) was estimated by the FAO method of PenmanMonteith from different climatic variables (Allen et al., 2006; Guevara, 2013). This method has been selected because it closely approximates the ETP of any evaluated location, has solid physical bases 
and explicitly incorporates physiological and aerodynamic parameters, described extensively in the study developed by Hernández et al. (2017).

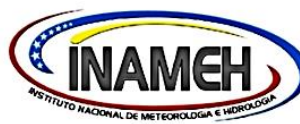

Instituto Nacional de Meteorología e Hidrología

Miranda-Venezuela

Leyenda

\section{Municipios \\ $\square$ BEJUMA \\ CARLOS ARVELO \\ DIEGO IBARRA \\ GUACARA \\ JUAN JOSÉ MORA \\ LIBERTADOR \\ LOS GUAYOS \\ MIRANDA \\ MONTALBÁN \\ NAGUANAGUA \\ PUERTO CABELLO \\ SAN DIEGO \\ SAN JOAQUIN \\ VALENCIA}

Simbolos convencionales

- Estaciones Pluviométricas

Estaciones Climatologicas

- Troncal

Hidrograf

ISP Perimetro Urbano

$\square$ cuerpos de Agua

-. j Cuencas Hidrograficas

-.-- Limite municipal
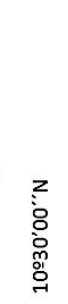

$6890,00 " \mathrm{~W}$

$67 \circ 30^{\prime} 00^{\prime \prime} \mathrm{W}$

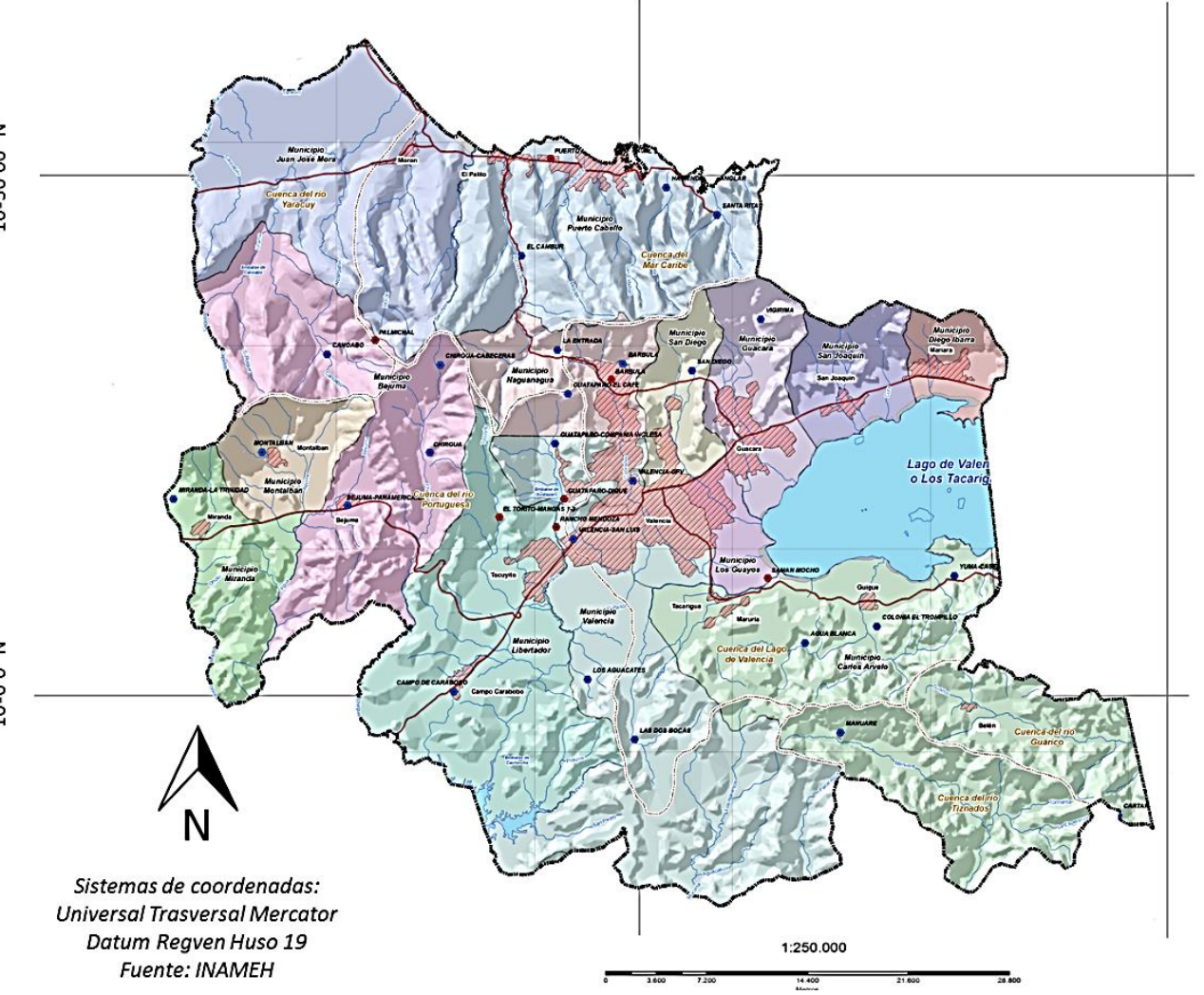

Figure 1. Spatial distribution of rainfall stations in the state of Carabobo, Venezuela.

Table 1

Geographic location of rainfall stations in the state of Carabobo, Venezuela

\begin{tabular}{|c|c|c|c|c|c|}
\hline watershed & Rainfall station & Municipality & North & East & $\begin{array}{c}\text { Altitud } \\
\text { (m.a.s.I.) }\end{array}$ \\
\hline \multirow{4}{*}{ Mar Caribe } & El Cambur & Puerto Cabello & 1148809 & 598736 & 80 \\
\hline & La Entrada & Naguanagua & 1139635 & 602382 & 510 \\
\hline & Hacienda El Manglar & Puerto Cabello & 1155581 & 613403 & 20 \\
\hline & Santa Rita & Puerto Cabello & 1152833 & 618430 & 38 \\
\hline \multirow{9}{*}{ Lago de Valencia } & Vigirima & Guacara & 1142558 & 622845 & 557 \\
\hline & San Diego & San Diego & 1137558 & 615956 & 460 \\
\hline & Valencia-GFV & Valencia & 1126726 & 609967 & 460 \\
\hline & Yuma-Caserio & Carlos Arvelo & 1117317 & 642415 & 460 \\
\hline & Colonia EI Trompillo & Carlos Arvelo & 1112434 & 634579 & 450 \\
\hline & Agua Blanca & Carlos Arvelo & 1110749 & 627339 & 515 \\
\hline & Las Dos Bocas & Valencia & 1101292 & 610166 & 550 \\
\hline & Bárbula & Naguanagua & 1136672 & 607806 & 493 \\
\hline & Valencia-San Luis & Valencia & 1120933 & 603958 & 470 \\
\hline \multirow{8}{*}{ Río Portuguesa } & Guataparo El Café & Naguanagua & 1135215 & 603369 & 1200 \\
\hline & Chirgua-Cabeceras & Bejuma & 1138036 & 590553 & 770 \\
\hline & Guataparo C. Inglesa & Valencia & 1130327 & 602075 & 530 \\
\hline & Montalbán & Montalbán & 1129486 & 572502 & 700 \\
\hline & Chirgua & Bejuma & 1129525 & 589480 & 740 \\
\hline & Bejuma-Panamericana & Bejuma & 1124314 & 581185 & 650 \\
\hline & Los Aguacates & Valencia & 1107115 & 605429 & 467 \\
\hline & Campo De Carabobo & Libertador & 1105972 & 591853 & 500 \\
\hline \multirow[t]{2}{*}{ Río Yaracuy } & Canoabo & Bejuma & 1139114 & 579052 & 300 \\
\hline & Miranda-La Trinidad & Miranda & 1124954 & 563534 & 628 \\
\hline Río Tiznados & Manuare & Carlos Arvelo & 1101914 & 630873 & 640 \\
\hline Río Guarico & Cartanal & Carlos Arvelo & 1093824 & 658988 & 620 \\
\hline
\end{tabular}


Given that the stations that are available in the state and its adjacencies are mostly of the Conventional Pluviometric type, we proceeded to consider the already estimated data of ETP by the Penman Monteith Method, which in its entirety are 25 points on a monthly and annual basis. These ETP values were correlated, analyzed according to the monthly behavior of the evaporation and related to the homogeneous natural areas. All this in order to have reliable meteorological data, which allow reducing the risk of an overestimation or underestimation of the information in the calculation of water balances.

\section{Climate Water Balances (BHC)}

The BHC was calculated for each climatological station under a programming language called Clipper (Hernández et al., 2017). The program compiles precipitation data and ETP at monthly level; and in relation to the algorithms of the formulas, mathematical equations and implicit statistics in the field of Agrometeorology, the program performs a processing of the data, elaborating the corresponding water balances that break down the storage values, excesses and deficit of water in soil depending on its depth and predominant texture, in addition to the slope of the terrain.

\section{Water Index}

Hydric climate types are the integral expression of the behavior of a set of variables at monthly level such as precipitation, air temperature, and real and potential evapotranspiration, which synthesized in a Water Index (Im), determine the existence of a certain type of climate and existing life conditions, potentially usable in the field of sowing through the interrelation with water balances.

Table 2

Climatic classification according to the Water Index

\begin{tabular}{|c|c|c|}
\hline Water Index & Symbol & Climate Type \\
\hline Greater than +100 & A & Per-humid \\
\hline+80.1 to +100 & B4 & humid \\
\hline+60.1 to +80 & B3 & humid \\
\hline+40.1 to +60 & B2 & humid \\
\hline+20.1 to +40 & B1 & humid \\
\hline+0.1 to +20 & $\mathrm{C} 2$ & Moist sub-humid \\
\hline-19.9 to 0 & C1 & Dry sub-humid \\
\hline-39.9 to -20 & D & semiarid \\
\hline Less than -40 & $\mathrm{E}$ & Arid \\
\hline
\end{tabular}

According to this, for the Carabobo state the hydric climatic types were determined based on the methodology proposed by Thornthwaite (1948), detailed in equation (1) and classifications in Table 2.

$I_{m}=\frac{\left(100^{\star} \text { Excess }\right)-\left(60^{\star} \text { Deficit }\right)}{E T P}$
Where $E$ = Excess of water during the year; $D=$ Water deficiency in the year; ETP = Potential Evapotranspiration.

\section{Results and discussión}

Analysis of the climatic types associated with the water index

From a climatic point of view, the Carabobo state is located between the humid equatorial climates to the south and the dry ones of the subtropical high pressures to the north. The former owe their origin to the presence of the Intertropical Convergence Zone (ITCZ) whose displacement defines the beginning of the rainy season for Venezuela; while the second ones occur as a consequence of the anticyclonic cell of the Azores Bermuda, which when approaching the Earth's equator in the low sun months for the northern hemisphere, contributes to diminish the existing humidity, generating a wide area of climatic calm where the precarious evolution of cloud systems, contributes to the existence of good weather (Hernández et al., 2017; Olivares et al., 2017b).

In the margin of these two structures the conditions allow the presence of the Tropical Climates of the Carabobo state and the rest of the country, with a few months influenced by the convergence and its influence on the genesis of rainfall (rainy season); and others dominated by the absence of these (dry season) within the field of the North Atlantic Subtropical Highlands (Olivares et al., 2016a, 2016b).

The various water climatic types of the Carabobo state can be classified into four large groups that from north to south are: Semi-arid (D); Dry Subhumid (C1); Subhumid Humid (C2) and Slightly Humid (B1), all with conditions that allow to differentiate them both by their spatiality within the entity, as by the physiography and influence that it exerts in the existing climatic conditions. Semi-arid zones (D)

The approximate surface for this climate type is $651 \mathrm{~km}^{2}$, which represents $14 \%$ of the total Carabobo state; It extends over the municipalities of Juan José Mora and Puerto Cabello in the coastal region up to approximately 1100 meters above sea level, and occupies the emblematic regions of Puerto Cabello, EI Palito and Morón, in the area known as the coastal plain of the center and west of the state where Paradoxically, there is a narrow coastal strip that borders the mountainous coastal system and only changes its configuration towards the western end of the Yaracuy River basin, where the landscape becomes a colinar, as in the case of Montalban. 


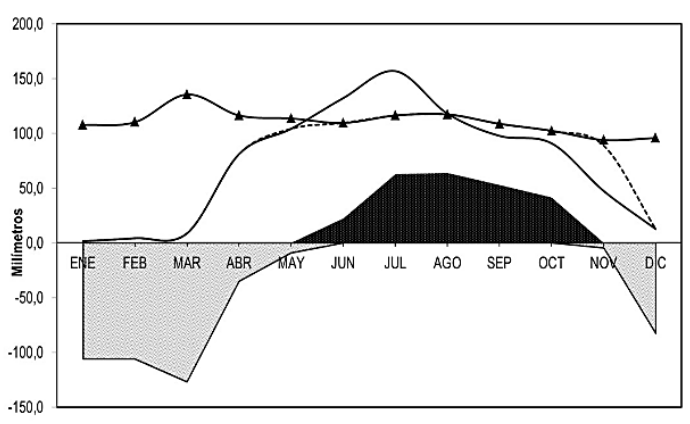

(a)

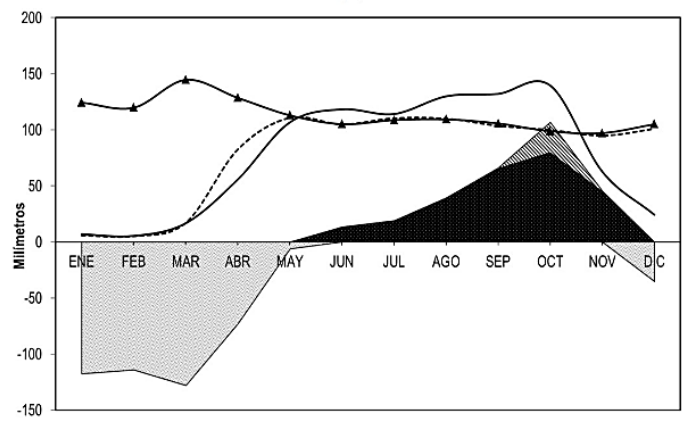

(c)

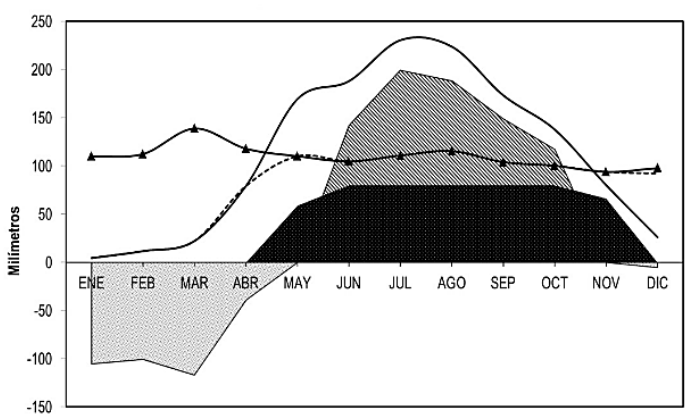

(e)

Wydric excesses Water storage Water deficit

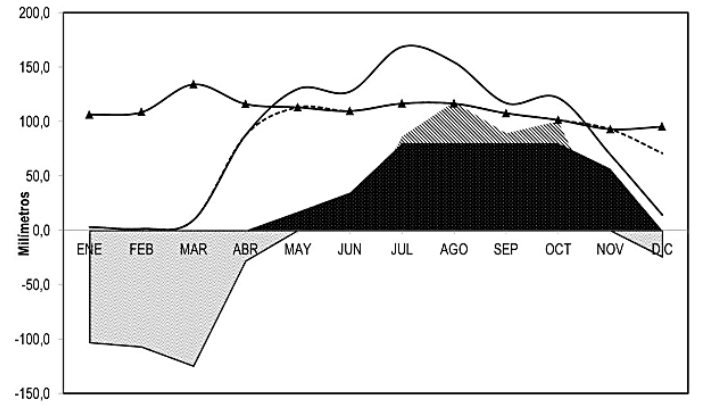

(b)

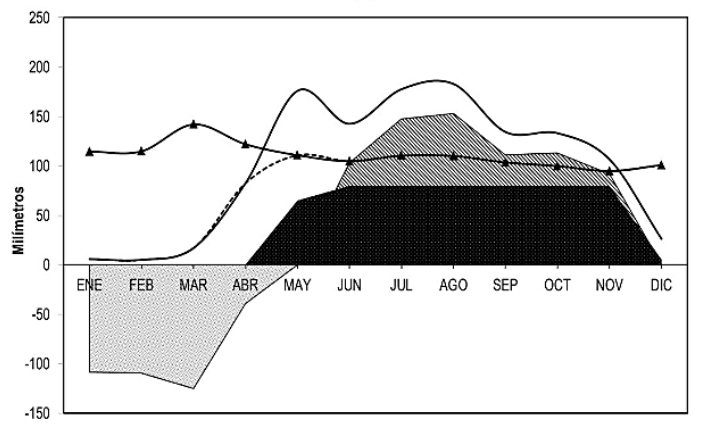

(d)

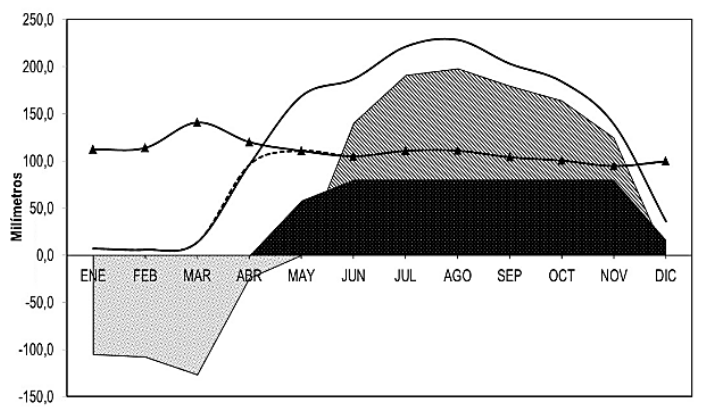

(f)

--- Real evapotranspiration

Figure 2. Water balance for each representative station (Considering the Storage Capacity: $80 \mathrm{~mm}$, Predominant soil texture: Medium, Depth: $50 \mathrm{~cm}$, General slope attributed to the whole area under study: <1\%, Potential Evapotranspiration by Penman- Monteith): (a) Montalbán (high deficit); (b) Chirgua Cabecera (moderate deficit); (c) Cartanal (moderate deficit); (d) Manaure (Low deficit); (e) Campo Carabobo (low deficit); (f) Las Dos Bocas (high excess).

According to the results, the $(\mathrm{Im})$ for the Montalbán station is -21.32 ; which determines the existence of a semi-arid climate with annual rainfall of $879 \mathrm{~mm}$. The water balance of the station (Figure 2a), indicates an amount of effective annual precipitation of about $850 \mathrm{~mm}$, with an annual (ETP) around $1327 \mathrm{~mm}$ and exceeds the rainfall throughout the year, except in the months of July and August this condition being translated in the presence of dry soils and permanent watercourses in low water conditions; In this subtype of climate there are no excesses of water.

Areas of the dry Sub-humid (C1)

This climatic type covers an area of $2791.15 \mathrm{~km}^{2}$ for $60 \%$ of the entire entity
(Table 3); it extends over the municipalities Miranda, Bejuma, Naguanagua, Los Guayos, San Diego, Guácara, San Joaquín and Diego Ibarra; as well as the northern end of the municipalities Libertador, Valencia, Carlos Arvelo; and southern end of the municipalities Juan José de Mora and Puerto Cabello. From the physiographic point of view there are wide contrasts due to the existing landscapes, presenting a mountainous relief to the north in the axis of the Cordillera de la Costa, a landscape bordering to the southwest in the region of Montalban, until finally the tectonic depression or valley of the basin of the Lake of Valencia in the central region.

The $(\mathrm{Im})$ for this region ranges from -2.16 to -18.96; which determines a dry sub-humid 
climate with annual rainfall ranging from $912 \mathrm{~mm}$ in the Cartanal station (Figure 2c) to $1033 \mathrm{~mm}$ in the Chirgua Cabecera (Figure 2b). In these sites, the effective annual rainfall is around $900 \mathrm{~mm}$, with an annual ETP of $1359 \mathrm{~mm}$ and only exceeds the precipitation during the months of November to April where the soils are dry and the permanent water courses in conditions of low water the month of November is characterized by the disappearance of the excesses but at the same time the presence of a significant amount of stored water that exceeds $60 \mathrm{~mm}$, reducing this value as the dry season is accentuated to show $0 \mathrm{~mm}$ of storage during the December where the exit of the waters gives way to deficits during January to April.

\section{Areas of the Moist sub humid (C2)}

This climatic type is located on an area of $883.86 \mathrm{~km}^{2}$ equivalents to $19 \%$ of the entire state; it extends over the northernmost area of the Valencia municipality and southern Libertador municipality, as well as the southwest of the Carlos Arvelo municipality, where the largest and most potential agricultural areas of the Carabobo state are located (Table 3 ).

The $(\mathrm{Im})$ for this zone is in the range of $\mathbf{0 . 6 9}$ to 13.45; what determines the presence of a humid sub-humid climate where the annual precipitations oscillate around $1238.1 \mathrm{~mm}$ in the Manaure station and 1376.1 in the Campo Carabobo station. The rainy season extends from May to October, precipitation exceeding the ETP indexes generating the presence of excesses that concentrate amounts of more than $300 \mathrm{~mm}$ per year and that greatly exceed the water storage capacity in soils (Figure $2 d$ ). The month of April, as in the lightly humid climatic type, behaves as a transitional period between the dry season and the rainy season, constituting the scenario where deficits begin to decrease as a result of the increase in rainfall rates (Figure $2 \mathrm{e}$ ).

\section{Slightly humid (B1)}

Politically it extends to the southern end of the Valencia municipality towards the limits with the Cojedes state, occupying an area of $325.63 \mathrm{~km}^{2}$ that represents $7 \%$ of the entire state (Table 3 ); The $(\mathrm{Im})$ for this region is 22.42; what determines a slightly humid climate where the annual precipitations oscillate around the $1536 \mathrm{~mm}$ according to the information of the station Las Dos Bocas. The rainfall regime (Figure $2 \mathrm{f}$ ) shows a Unimodal type distribution with two clearly defined periods; the rainy season, from May to October, extends even until November, where $88 \%$ of the rainfall is concentrated, with an annual maximum of $237 \mathrm{~mm}$ for the month of August; and the dry season from December to April, where the remaining $12 \%$ of the amount of precipitated water is concentrated. During the rainy season, the excesses occur because the precipitation exceeds the ETP indexes, concentrating a total of $515 \mathrm{~mm}$ accumulated from June to November that are a consequence of the saturation of the water storage capacity in the soils, generating scenarios of surface runoff and increase of water levels in rivers and streams.

Table 3

Surface $\left(\mathrm{km}^{2}\right)$ of the climatic types associated with the water index in the agricultural areas of Carabobo, Venezuela

\begin{tabular}{llcc}
\hline Agricultural location & Municipality & Climate type & Surface $\left(\mathbf{k m}^{2}\right)$ \\
\hline Hacienda El Manglar & Puerto Cabello & Semi-arid & $\mathbf{6 5 1 . 0}$ \\
\hline El Cambur & Puerto Cabello & & \\
La Entrada & Naguanagua & & \\
Canoabo & Bejuma & & \\
Miranda-La Trinidad & Miranda & & \\
Santa Rita & Puerto Cabello & & \\
Vigirima & Guacara & & \\
San Diego & San Diego & & \\
Valencia-GFV & Valencia & & \\
Yuma-Caserio & Carlos Arvelo & Dry sub-humid & \\
Colonia EI Trompillo & Carlos Arvelo & & \\
Cartanal & Carlos Arvelo & & \\
Bárbula & Naguanagua & & \\
Valencia-San Luis & Valencia & & \\
Guataparo El Café & Naguanagua & & \\
Chirgua-Cabeceras & Bejuma & & \\
Guataparo C. Inglesa & Valencia & & \\
Montalbán & Montalbán & & \\
Chirgua & Bejuma & & \\
Bejuma-Panamericana & Bejuma & & \\
\hline Los Aguacates & Valencia & & \\
Campo De Carabobo & Libertador & & \\
Agua Blanca & Carlos Arvelo & Moist sub humid & \\
Manuare & Carlos Arvelo & & \\
\hline Las Dos Bocas & Valencia & Slightly humid & \\
\hline
\end{tabular}


Implications of water deficit and excess

The highest annual values $(686 \mathrm{~mm})$ are presented at the Hacienda El Manglar station distributed throughout the year, followed by Montalbán and Miranda La trinidad, with annual amounts of $470 \mathrm{~mm}$ in both seasons (Table 4), due to the scarce precipitation.

It is convenient to indicate that the date of sowing of a crop is related to the yields that can be obtained, especially if it depends on the precipitation as the only source of water. The case of corn, and some cereals in Carabobo, is important to explain, since farmers wait for the first rains to prepare the soil and later sow; then that the crop takes advantage of the period of greater precipitation to complete its vegetative and reproductive period.

In this zone, the critical period of the crops that are normally sown, coincides with the period of highest precipitation, thus guaranteeing a good availability of water. At the time of harvest, the rainy season is culminating, allowing these short-cycle crops to complete their physiological maturity and harvesting machines and labor to easily harvest.

In this order of ideas, if the planting is done very early (April) there is a risk that the crop does not have enough moisture in its critical period and therefore its yields will be low, and if it is sown too late then there will be excess moisture associated with watering, poor availability of oxygen in the soil and low yields (Casanova, 2005; Cortez et al., 2016).

It is to be noted that crops use, for their growth and biological functions, only $2 \%$ of the water that enters their roots, the rest is removed in the form of water vapor to the atmosphere, so that by measuring the current evapotranspiration we have a very approximate value of the water needs of the plant, because although they use a very low percentage of the water absorbed to grow and develop, it is essential to circulate the rest for the distribution of the nutrients dissolved in the water to the entire plant organism (De Ondiz, 2008).

In the arid zones located to the north of the Carabobo state, characterized by scarce rainfall or rainfall distributed in a few months of the year, it will be essential to resort to irrigation to achieve the growth and fruiting of the crops within their cycle. The number of harvests will depend on the availability of water stored in the reservoir, so the absence of this collection work would leave the land unproductive.

In those areas of the Carabobo state, especially the agricultural localities located in the dry Subhumid climatic type, which require complementary irrigation, but have a defined rainy period and with extensions that are equal to or greater than the crop cycle, it is possible to combine the irrigation and rainfed to reach no less than two crops per year in short-cycle crops.

Table 4

Annual distribution of water deficit $(\mathrm{mm})$ for the study area

\begin{tabular}{|c|c|c|c|c|c|c|c|c|c|c|c|c|}
\hline $\begin{array}{l}\text { Agricultural } \\
\text { location }\end{array}$ & jan & feb & mar & apr & may & jun & jul & agu & sep & oct & nov & dec \\
\hline Vigirima & 103.5 & 107.6 & 129.7 & 67.6 & 0.0 & 0.0 & 0.0 & 0.0 & 0.0 & 0.0 & 0.0 & 10.4 \\
\hline San Diego & 105.3 & 108.6 & 130.1 & 64.0 & 0.0 & 0.0 & 0.0 & 0.0 & 0.0 & 0.0 & 0.0 & 34.4 \\
\hline La Entrada & 102.5 & 105.4 & 123.4 & 51.8 & 0.0 & 0.0 & 0.0 & 0.0 & 0.0 & 0.0 & 0.0 & 16.6 \\
\hline El Cambur & 85.4 & 92.1 & 120.7 & 46.6 & 14.7 & 20.3 & 0.0 & 0.0 & 0.0 & 0.0 & 0.0 & 0.0 \\
\hline Chirgua & 102.2 & 108.9 & 133.8 & 47.6 & 0.0 & 0.0 & 0.0 & 0.0 & 0.0 & 0.0 & 0.0 & 33.7 \\
\hline Montalbán & 106.0 & 106.0 & 126.8 & 35.2 & 9.4 & 0.0 & 0.0 & 0.0 & 0.0 & 0.0 & 5.0 & 83.2 \\
\hline Guataparo & 102.8 & 106.2 & 128.1 & 54.6 & 0.0 & 0.0 & 0.0 & 0.0 & 0.0 & 0.0 & 0.0 & 10.7 \\
\hline Chirgua Cabecera & 103.2 & 107.2 & 124.6 & 28.4 & 0.0 & 0.0 & 0.0 & 0.0 & 0.0 & 0.0 & 0.0 & 24.4 \\
\hline Las Dos Bocas & 105.2 & 108.0 & 127.1 & 24.0 & 0.0 & 0.0 & 0.0 & 0.0 & 0.0 & 0.0 & 0.0 & 0.0 \\
\hline $\begin{array}{l}\text { Bejuma } \\
\text { Panamericana }\end{array}$ & 102.9 & 107.9 & 125.4 & 35.0 & 0.0 & 0.0 & 0.0 & 0.0 & 0.0 & 0.0 & 0.0 & 20.9 \\
\hline Canoabo & 99.8 & 101.7 & 127.4 & 54.3 & 17.3 & 33.9 & 7.4 & 12.2 & 3.3 & 0.0 & 0.0 & 11.4 \\
\hline $\begin{array}{l}\text { Miranda La } \\
\text { Trinidad }\end{array}$ & 104.2 & 111.0 & 126.4 & 42.5 & -2.4 & 0.0 & 0.0 & 0.0 & 0.0 & 0.0 & 16.0 & 67.5 \\
\hline Santa Rita & 86 & 101.1 & 124.2 & 60.4 & -26 & 22.5 & 0.0 & 0.0 & 0.0 & 0.0 & 0.0 & 0.0 \\
\hline Bárbula & 104.1 & 106.8 & 130.7 & 50.7 & 0.0 & 0.0 & 0.0 & 0.0 & 0.0 & 0.0 & 0.0 & 19.8 \\
\hline Agua Blanca & 108.7 & 107.5 & 128.7 & 40.4 & 0.0 & 0.0 & 0.0 & 0.0 & 0.0 & 0.0 & 0.0 & 0.0 \\
\hline Guataparo El Cafe & 101.6 & 106.4 & 124.6 & 53.1 & 0.0 & 0.0 & 0.0 & 0.0 & 0.0 & 0.0 & 0.0 & 23.0 \\
\hline $\begin{array}{l}\text { Hacienda El } \\
\text { Manglar }\end{array}$ & 89.2 & 98.9 & 117.6 & 64.9 & 57.9 & 49.8 & 20.6 & 35.8 & 45.2 & 25.8 & 33.6 & 46.9 \\
\hline $\begin{array}{l}\text { Colonia El } \\
\text { Trompillo }\end{array}$ & 112.1 & 112.6 & 137.5 & 72.3 & 0.0 & 0.0 & 0.0 & 0.0 & 0.0 & 0.0 & 0.0 & 7.5 \\
\hline Yuma Caserio & 112.2 & 116.3 & 139.2 & 72.4 & -2.4 & 0.0 & 0.0 & 0.0 & 0.0 & 0.0 & 0.0 & 51.4 \\
\hline Valencia GFV & 106.3 & 109.3 & 131.3 & 46.7 & 0.0 & 0.0 & 0.0 & 0.0 & 0.0 & 0.0 & 0.0 & 36.3 \\
\hline Valencia San Luis & 107.4 & 107 & 129.1 & 38.5 & 0.0 & 0.0 & 0.0 & 0.0 & 0.0 & 0.0 & 0.0 & 30.9 \\
\hline Los Aguacates & 106.5 & 111.4 & 131 & 45.4 & 0.0 & 0.0 & 0.0 & 0.0 & 0.0 & 0.0 & 0.0 & 0 \\
\hline Campo Carabobo & 105.4 & 100.7 & 116.7 & 38.7 & 0.0 & 0.0 & 0.0 & 0.0 & 0.0 & 0.0 & 0.0 & -5.4 \\
\hline Manaure & 108.7 & 109.8 & 125 & 39.3 & 0.0 & 0.0 & 0.0 & 0.0 & 0.0 & 0.0 & 0.0 & 0.0 \\
\hline Cartanal & 117.4 & 114.3 & 127.9 & 72.7 & -6.2 & 0.0 & 0.0 & 0.0 & 0.0 & 0.0 & 0.0 & 35.3 \\
\hline
\end{tabular}


Table 5

Annual distribution of excess water $(\mathrm{mm})$ for the study area

\begin{tabular}{|c|c|c|c|c|c|c|c|c|c|c|c|c|}
\hline Agricultural location & jan & feb & mar & apr & may & jun & jul & agu & sep & oct & nov & dec \\
\hline La Entrada & 0.0 & 0.0 & 0.0 & 0.0 & 0.0 & 0.0 & 47.8 & 44.2 & 37.9 & 22.0 & 0.0 & 0.0 \\
\hline Chirgua & 0.0 & 0.0 & 0.0 & 0.0 & 0.0 & 0.0 & 5.0 & 35.4 & 34.9 & 11.0 & 0.0 & 0.0 \\
\hline Montalbán & 0.0 & 0.0 & 0.0 & 0.0 & 0.0 & 0.0 & 0.0 & 0.0 & 0.0 & 0.0 & 0.0 & 0.0 \\
\hline Guataparo & 0.0 & 0.0 & 0.0 & 0.0 & 0.0 & 3.8 & 55.8 & 61.7 & 47.4 & 20.1 & 0.0 & 0.0 \\
\hline Bejuma Panamericana & 0.0 & 0.0 & 0.0 & 0.0 & 0.0 & 0.0 & 38.0 & 39.0 & 6.4 & 1.3 & 0.0 & 0.0 \\
\hline Canoabo & 0.0 & 0.0 & 0.0 & 0.0 & 0.0 & 0.0 & 0.0 & 0.0 & 0.0 & 0.0 & 0.0 & 0.0 \\
\hline Miranda La Trinidad & 0.0 & 0.0 & 0.0 & 0.0 & 0.0 & 0.0 & 0.0 & 0.0 & 0.0 & 0.0 & 0.0 & 0.0 \\
\hline Santa Rita & 0.0 & 0.0 & 0.0 & 0.0 & 0.0 & 0.0 & 0.0 & 0.0 & 0.0 & 0.0 & 30.8 & 0.0 \\
\hline Bárbula & 0.0 & 0.0 & 0.0 & 0.0 & 0.0 & 0.0 & 37.7 & 60.5 & 44.3 & 24 & 0.0 & 0.0 \\
\hline Agua Blanca & 0.0 & 0.0 & 0.0 & 0.0 & 0.0 & 23.3 & 69.2 & 73.9 & 67.3 & 46.4 & 0.0 & 0.0 \\
\hline Valencia GFV & 0.0 & 0.0 & 0.0 & 0.0 & 0.0 & 0.0 & 8.9 & 42.4 & 43.5 & 24.6 & 0.0 & 0.0 \\
\hline Valencia San Luis & 0.0 & 0.0 & 0.0 & 0.0 & 0.0 & 11.7 & 66.1 & 57.9 & 42.9 & 27.4 & 0.0 & 0.0 \\
\hline Los Aguacates & 0.0 & 0.0 & 0.0 & 0.0 & 0.0 & 27.3 & 102.9 & 89.7 & 83.6 & 67.9 & 6.4 & 0.0 \\
\hline Campo Carabobo & 0.0 & 0.0 & 0.0 & 0.0 & 0.0 & 62.4 & 119.6 & 108.4 & 69.3 & 37.6 & 0.0 & 0.0 \\
\hline Manaure & 0.0 & 0.0 & 0.0 & 0.0 & 0.0 & 23 & 67.2 & 72.9 & 30.8 & 33.2 & 11.8 & 0.0 \\
\hline Cartanal & 0.0 & 0.0 & 0.0 & 0.0 & 0.0 & 0.0 & 0.0 & 0.0 & 0.0 & 26.5 & 0.0 & 0.0 \\
\hline
\end{tabular}

On the other hand, Table 5 shows the distribution of excess water. In the areas south of Carabobo where it rains most of the year (Las Dos Bocas station), crops that the cultivation cycle and the times of preparation of land and crops allow, will not require complementary artificial irrigation.

The shorter the rainy period, the more water will be necessary to import, the greater the complementary irrigation to be able to have one or more crops of a given crop.

In the basin of the lake of Valencia, a large part of the crops raised with artificial irrigation are not subject to the vagaries of the rain, with eventual droughts that can generate crop losses or with storms of intense rainfall that damage the crops by asphyxia at the root level, unless large investments of surface and subsurface drainage are made.

The regulation of rainfall variations is usually achieved with reservoirs that guarantee storage volumes that can be used among other applications for irrigation and flood control. In this way, a drought will not be so bad if you have a quantity of water previously stored to irrigate, or a flood will not generate so much damage downstream, if you have in the reservoir the volume needed to store them (De Ondiz, 2008).

For the period analyzed, the results described show that the phenomenon ENSO (EI Niño-Southern Oscillation) can partially explain the occurrence of extremely dry months or Wet extremes at local scale during the wet and dry seasons in the lake basin of Valencia (Paredes et al., 2014; Paredes et al., 2015; Pérez, 2012).

\section{Climate adaptability strategies}

The climate change observed during the last decades has deepened the vulnerability of the populations most in need and the agroecosystems of the central region of Venezuela, especially in the state of Carabobo. Generally, part of the agricultural areas suffers from a socio-environmental crisis derived from the implementation of intensive extractive and agroexport models, as well as public policies with gaps that benefit only a part of the population (Ovalles et al., 2008; MARN, 2005). The water crisis in the region has been accelerated in the last thirty years with the decrease in river flows and water births, affecting mainly the rural population and small farmers, which has led to a high growth in the prices of agricultural goods, causing, in this way, a higher level of food insecurity.

In general, adaptation to climate change is defined as adjustments in natural or human systems in response to projected or real climatic stimuli, or their effects, which may moderate the damage or take advantage of its beneficial aspects (IPCC, 2007).

Many of the measures necessary to reduce the effects of climate change or adapt to it are valuable to address other existing problems such as water and air pollution, soil erosion and vulnerability to droughts or floods.

Faced with this panorama, action lines and adaptation measures appear in agriculture 
as a climatically sensitive activity, focused on promoting changes in food goods systems (production and storage of basic foods and agricultural inputs and their commercialization); changes in the activities of food systems (the form of production, storage, consumption and distribution) and, finally, changes in food security components (availability, access, utilization and stability of food). Table 6 shows the adaptation measures in agricultural territories of Carabobo, where the capacity of adaptation and elasticity of the population are increased through the adoption of sustainable production systems and practices. Basically, the development of new technologies is prioritized for areas with scarce land or water or with special soil or climate problems (example: no-till or conservation agriculture, use of less pest or integrated nutrient management inputs, agriculture) organic, use of biotechnology to overcome environmental pressures (drought, waterlogging, soil acidity, salinity and extreme temperatures, pests and diseases). Climate change is the consequence of a global negative externality but its solution leads to modify the current patterns of production and consumption and the formation of a new economy that implies the formation of a new style of development.

Measures for resilience cover legal, political, technological and educational aspects at different levels of society's organization. Drought-resistant crop varieties are being incorporated in the country, there are examples of management practices that prevent land degradation and improve their sustainability (reduced tillage, use of amendments and fertilizers, land drainage, among others) (IANAS, 2017).

In the area of climate and integrated management of water resources, the National Institute of Meteorology and Hydrology has a monitoring system of hydrometeorological conditions, forecasts and numerical weather prediction that facilitate the strategic and operational planning of agricultural work in the areas of greater importance. This institution aims to improve the networks for the measurement of climate, soil, hydrology and water quality and its integration in support systems for decision making.

The Carabobo state has abundant water resources distributed in hydrographic systems. However, the north of the Orinoco, where the population is concentrated, confronts problems of water availability. The entity has three reservoirs built for various purposes: potable water supply, industrial use, irrigation, flood control, (González and Matos, 2012).

In 2014 there were a total of 745300 ha irrigated $(2.9 \%$ of the agricultural area) and 910000 ha drained in the national territory. That is why among the challenges in the use of water resources, are: the application of measures to solve problems of eutrophication, clogging (fill of dams by sediment derived from erosion), pollution, decreased water flow and conflicts of use, in addition to improving the efficiency of water use in the agricultural, urban and industrial sectors.

Table 6

Climatic adaptation measures for rainfed agricultural territories in Carabobo, Venezuela

\begin{tabular}{|c|c|c|c|c|}
\hline Line of action & Location & Adaptation measures & $\begin{array}{l}\text { Scope of } \\
\text { adoption }\end{array}$ & $\begin{array}{l}\text { Scope of } \\
\text { incidence }\end{array}$ \\
\hline $\begin{array}{l}\text { Agricultural } \\
\text { diversification }\end{array}$ & $\begin{array}{l}\text { watersheds } \\
\text { of the Lake } \\
\text { of Valencia } \\
\text { and } \\
\text { The } \\
\text { Portuguese } \\
\text { River } \\
\text { watersheds }\end{array}$ & $\begin{array}{l}\text { - Rescue of native species } \\
\text { - Reduction of agrochemical inputs } \\
\text { - Strengthening of the germplasm bank } \\
\text { - Formal training in sustainable practices } \\
\text { - Technology transfer oriented to sustainable } \\
\text { practices } \\
\text { - Promotion of collectives dedicated to the } \\
\text { production of native seed } \\
\text { - Collectivization of land for good practices }\end{array}$ & $\begin{array}{l}\text { Familiar and } \\
\text { local through } \\
\text { the collective } \\
\text { producers }\end{array}$ & $\begin{array}{l}\text { Municipal } \\
\text { /sectorial }\end{array}$ \\
\hline $\begin{array}{l}\text { Management } \\
\text { of the most } \\
\text { vulnerable } \\
\text { watersheds }\end{array}$ & $\begin{array}{l}\text { High, } \\
\text { medium and } \\
\text { low areas of } \\
\text { watersheds }\end{array}$ & $\begin{array}{l}\text { - Sensitization of the population in terms of } \\
\text { conservation of resources } \\
\text { - Reforestation of the upper area of the basins } \\
\text { - Construction of live barriers }\end{array}$ & $\begin{array}{c}\text { Official } \\
\text { organizations } \\
\text { such as } \\
\text { ministries and } \\
\text { research } \\
\text { institutions }\end{array}$ & $\begin{array}{c}\text { Statel } \\
\text { Regional }\end{array}$ \\
\hline $\begin{array}{l}\text { Strengthening } \\
\text { collective } \\
\text { initiatives }\end{array}$ & $\begin{array}{l}\text { watersheds: } \\
\text { Portuguese } \\
\text { River, } \\
\text { Tiznados } \\
\text { River, } \\
\text { Yaracuy } \\
\text { River and } \\
\text { Lake of } \\
\text { Valencia }\end{array}$ & $\begin{array}{l}\text { - For producers dedicated to subsistence } \\
\text { agriculture: creation of a local space for the } \\
\text { commercialization of production } \\
\text { - For young producers: promotion of the } \\
\text { formation of new producer groups } \\
\text { - For producers of conventional agriculture: } \\
\text { strengthening their capacities through } \\
\text { theoretical-practical training processes that } \\
\text { allow them to increase their local knowledge, } \\
\text { cultural identity and self-sustainability. }\end{array}$ & $\begin{array}{l}\text { Community } \\
\text { and union } \\
\text { organizations }\end{array}$ & $\begin{array}{l}\text { Local/ } \\
\text { Municipal }\end{array}$ \\
\hline
\end{tabular}


State institutions do not have a good dissemination of their Strategic Plans and there is no adequate articulation between them in order to carry out comprehensive actions in this area.

Likewise, it is necessary to overcome the distinction between public and private, recognizing that the current challenges faced by agriculture require cohesive, comprehensive and shared action (MARN, 2005).

In addition, there is sufficient legal support to take actions regarding the adaptation of the agricultural sector; However, these instruments have been little applied and some of them, among which is the Land Law, restrict the flexibility in relation to decision-making to establish short-term measures that imply territorial planning plans regarding the agricultural uses (Ovalles et al., 2008).

In addition to the above, regular resources should be available for the implementation of the programs of dissemination, training, support for research and implementation of measures to adapt to climate change by agricultural producers. A contingency fund should be established to allocate resources for the implementation of reactive measures before the uncertainty of climate variability and extreme events. It is essential to design programs of scientific and technological development integrated to the productive dynamics; the provision and training for the use of Information and Communication Technologies (ICT) for precision agriculture and to organize and implement technical assistance plans for producers.

Finally, it is necessary to strengthen the social organization, promote cooperatives for small, medium and large producers to achieve mainly the reduction in input costs and a more efficient marketing of their products.

\section{Conclusions}

The study concentrates the results of the BHC, which allowed to know the interannual variation of the deficit and excesses. In this way, the influence that climate interannual variability can exert on the climate characterization of Carabobo, and its impact on agricultural areas, is highlighted. This allows us to suggest the use of this methodology to obtain the values of deficits and excesses resulting from the BHC, for planning purposes, zoning and characterization of the water regime of any location.

Considering the magnitude of the water deficit in these agricultural areas of the
Carabobo state, severe dry episodes would have to be faced through a greater endowment of resources for the construction of deep wells, taking advantage also of the rivers and nearby streams; For this, it is necessary to have a strategic plan at the regional level to determine the most important river basins in the area, in order to generate a reserve to enhance irrigation in the agricultural sector. The results show that the evaluation of the risks of deficit and excess water in potential areas for crops will facilitate the creation of a database in support of the ecological order of the Carabobo state. This would allow in the long term, to carry out a sustainable management of the natural resources from a deep knowledge of the potentialities, as well as their conservation with prior knowledge.

\section{Acknowledgments}

We appreciate the financial support of the Secretariat of Food Security and Agrarian Development of the Government of Carabobo State, Venezuela.

\section{References}

Ablan, M.; Andressen, R.; Vargas, M. P.; Acevedo, M. 2008. Propuesta metodológica para el control de calidad de datos de precipitación. Agronomía Trop 58(1): 57-60.

Allen, R.G.; Pereira, L.S.; Raes, D.; Smith, M. 2006. Evapotranspiración del cultivo. Guías para la determinación de los requerimientos de agua de los cultivos. Roma, Italia, FAO. 323 p. (Serie Estudio de Riego y Drenaje No. 56).

Alzate, D.F.; Araujo, G.; Rojas, E.; Gómez, D.; Martínez, F. 2018. Interpolación regnie para lluvia y temperatura en las regiones andina, caribe $y$ pacífica de Colombia. Colombia Forestal 21(1): 102118.

Casanova, E. 2005. Introducción a la ciencia del suelo. Editorial del Consejo de desarrollo científico y humanístico. UCV. Caracas, Venezuela. 482 pp.

Cortez, A.; Rodríguez, M.; Rey, J.C.; Ovalles, F.; González, W.; Parra, R.; Olivares, B; Marquina, J. 2016. Variabilidad espacio temporal de la precipitación en el estado Guárico, Venezuela. Rev. Fac. Agron (LUZ) 33 (3): 292-310.

De Ondiz, J. 2008. Riego y drenaje agrícola para ingenieros. Editorial del Consejo de Desarrollo Científico y Humanístico. UCV. Caracas, Venezuela. 662 p.

Di Rienzo, J.A.; Casanoves F.; Balzarini M.G.; González L.; Tablada M.; Robledo C.W. 2011. InfoStat versión 2011. Grupo InfoStat, FCA, Universidad Nacional de Córdoba, Argentina. Disponible en: http://www.infostat.com.ar

ESRI. 1996. Arc View GIS. The geographic information system for everyone. Versión 3.2. by ESRI. Product ID: 825921104087.

García, G.C; Ciari, G.; Gaitan, J.; Caruso, C.; Nagahama, N.; Opazo, W.; Nakamatsu, V.; Lloyd, C.; Cotut, C.; Irisarri, G.; Escobar, J. 2017. Análisis de la evolución del clima y los pastizales naturales en el noroeste de la provincia de Chubut, Argentina, durante el período 2000-2014: identificación de variables asociadas a la disminución de las existencias ganaderas en la región. Agriscientia 34(1): 59-69. 
González, E.; Matos L. 2012. Manejo de los recursos hídricos en Venezuela. En: Diagnóstico del agua en las Américas. Jiménez C., B. y Galizia T., J. (Eds). México, IANAS-Foro Consultivo Científico y Tecnológico, AC. pp. 437-445.

Guevara, J.M. 2013. Métodos de estimación y ajuste de datos climáticos. Editorial del Consejo de desarrollo científico y humanístico. UCV. Caracas, Venezuela. $127 \mathrm{p}$.

Hernández, R.; Pereira, Y.; Molina, J.C.; Coelho, R.; Olivares, B; Rodríguez, K. 2017. Calendario de siembra para las zonas agrícolas del estado Carabobo en la República Bolivariana de Venezuela. Editorial Universidad Internacional de Andalucía. Sevilla, España. 247 pp.

IANAS (Red Interamericana de Academias de Ciencias, México). 2017. Retos y oportunidades de la seguridad alimentaria y nutricional en las Américas El punto de vista de las Academias de Ciencias. México, IANAS. $637 \mathrm{pp}$.

IPCC (Intergovernmental Panel on Climate Change, Switzerland). 2007. Climate Change 2007: Impacts, Adaptation and Vulnerability. Contribution of Working Group II to the Fourth Assessment Report of the Intergovernmental Panel on Climate Change, Annex I., M.L. Parry, O.F. Canziani, J.P. Palutikof, P.J. van der Linden y C.E. Hanson, Eds., United Kingdom y New York, USA, Cambridge University Press.

Jones, B.; Sall, J. 2011. JMP statistical discovery software. Wiley Interdisciplinary Reviews: Computational Statistics 3(3): 188-194.

MARN (Ministerio del Ambiente y de los Recursos Naturales, Venezuela). 2005. Primera Comunicación Nacional en Cambio Climático de Venezuela. Programa de las Naciones Unidas para el Desarrollo (PNUD). Caracas, Venezuela. 134. p.

Olivares, B.; Caraballo, L.; Torrealba, J. 2013a. Variabilidad del régimen de precipitación en el periodo 1990-2009 en la localidad de El Tigre estado Anzoátegui, Venezuela. Rev. Fac. Agron (LUZ) 30(1): 19-32.

Olivares, B. 2018. Condiciones tropicales de la lluvia estacional en la agricultura de secano de Carabobo, Venezuela. La Granja: Revista de Ciencias de la Vida 27(1): 86-102.

Olivares, B.; Cortez, A.; Lobo, D.; Parra, R., Rey, J.C.; Rodríguez, M. 2016a. Estudio de la Sequía Meteorológica en Localidades de los Llanos de Venezuela Mediante el Índice de Precipitación Estandarizado. Revista Acta Nova 7(3): 266-283.

Olivares, B.; Cortez, A.; Lobo, D.; Parra, R.; Rey, J.C.; Rodríguez, M. 2016b. Análisis temporal de la sequía meteorológica en localidades semiáridas de Venezuela. UGCiencia 22 (1): 11-24.

Olivares, B.; Cortez, A.; Lobo, D.; Parra, R.; Rey, J.C.; Rodríguez, M. 2017a. Evaluation of agricultural vulnerability to drought weather in different locations of Venezuela. Rev. Fac. Agron. (LUZ) 34(1): 103-129.

Olivares, B.; Cortez, A.; Muñetones, A.; Casana, S. 2016c. Strategic Elements of Organizational Know- ledge Management for Innovation. Case: Agrometeorology Network. Revista Digital de Investigación en Docencia Universitaria 10(1): 68-81.

Olivares, B.; Cortez, A.; Parra, R.; Rodríguez, M.; Guevara, E. 2013b. Aplicación de procedimientos estadísticos para el control de calidad de las series de precipitación mensual de los llanos orientales venezolanos. Rev. Fac. Agron (LUZ) 30(3): 367-391.

Olivares, B.; Parra, R.; Cortez, A. 2017c. Caracterización de los patrones de precipitación en el estado Anzoátegui, Venezuela. Ería 3(3): 353-365.

Olivares, B.; Parra, R.; Cortez, A.; Rodríguez, M.F. 2012. Patrones de homogeneidad pluviométrica en estaciones climáticas del estado Anzoátegui, Venezuela. Revista Multiciencias 12 (Ext.): 11-17.

Olivares, B.; Zingaretti, M.L.; Demey Zambrano, J.A.; Demey, J.R. 2017b. Aplicación del método STATISACT al régimen de lluvias en la Región Oriental Venezolana. UNED Research Journal 9(1): 97-106.

OMM (Organización Meteorológica Mundial, Suiza). 2011. Guía de prácticas climatológicas. OMMN¹00. Ginebra. Suiza. 128 pp.

Ovalles, F.; Cortez, A.; Rodríguez, M.F.; Rey, J.C.; Cabrera-Bisbal, E. 2008. Variación geográfica del impacto del cambio climático en el sector agrícola en Venezuela. Agronomía Trop 58 (1): $37-40$.

Paredes, F.; Guevara-Pérez, E.; Barbosa-Alves, H.; Uzcátegui-Briceño, C. 2015. Tendencia de la precipitación estacional e influencia de EI NiñoOscilación Austral sobre la ocurrencia de extremos pluviométricos en la cuenca del lago. Tecnología y Ciencias del Agua VI (6): 33-48.

Paredes, F.; La Cruz, F.; Guevara, E. 2014. Análisis regional de frecuencia de las sequías meteorológicas en la principal región cerealera de Venezuela. Bioagro 26(1): 21-28.

Parra, R.; Cortez, A. 2005. Control de calidad de series de precipitación de las series de precipitación del INIA Venezuela en el periodo 1970-2000. Rev. Arg. de Agrometeorología (5-6): 63-73.

Pérez, N.L. 2012. Influencia de episodios EI NiñoOscilación del Sur (ENOS) sobre la precipitación en el Estado Monagas, Venezuela. Revista Científica UDO Agrícola 12(2): 400-406.

Rodríguez, M.F.; Cortez, A.; Olivares, B.; Rey, J.C.; Parra, R.; Lobo, D. 2013. Análisis espacio temporal de la precipitación del estado Anzoátegui y sus alrededores. Agronomía Trop 63 (1-2): 57-65.

Ruiz-Álvarez, O.; Arteaga-Ramírez, R.; Vázquez-Peña, M.A.; Ontiveros Capurata, R.E.; López-López, R. 2012. Balance hídrico y clasificación climática del estado de Tabasco, México. Universidad y Ciencia 28(1): 1-14.

Thornthwaite, C.W. 1948. An approach toward a rational classification of climate. American Geographical Society 38(1): 55-94.

Zubieta, R.; Saavedra, M.; Silva, Y.; Giráldez, L. 2017. Spatial analysis and temporal trends of daily precipitation concentration in the Mantaro River basin: Central Andes of Peru. Stochastic Environmental Research and Risk Assessment 31(6): 1305-1318. 